\title{
PENGARUH ARTIFICIAL INTELLIGENCE DAN DIGITAL MARKETING TERHADAP MINAT BELI KONSUMEN
}

\author{
Franycia Maria Pangkey1; Lalu M. Furkan2; Lalu Edy Herman ${ }^{3}$ \\ ${ }^{1}$ Magister Manajemen Fakultas Ekonomi dan Bisnis, Universitas Mataram \\ E-mail: franyciapangkey@gmail.com \\ 2Fakultas Ekonomi dan Bisnis, Universitas Mataram \\ E-mail: lalu.furkan@gmail.com \\ ${ }^{3}$ Fakultas Ekonomi dan Bisnis, Universitas Mataram \\ 3E-mail: ehlalu@gmail.com
}

\begin{abstract}
ARTICLE INFO
Keywords :

Consumer Buying Intentions, Artificial Intelligence, Digital Marketing, Online Transportation

\section{Kata Kunci :}

Artificial Intelligence, Digital Marketing, Minat Beli Konsumen

How to cite :

Maria Pangkey, Franycia., Furkan, ML., Edy Herman, Lalu., (2019). Pengaruh Artificial Intelligence Dan Digital Marketing Terhadap Minat Beli Konsumen, 8(3),258-269
\end{abstract}

DOI :

http://dx.doi.org/10.29303/jmm.v8i3.448

$\begin{array}{ll}\text { Dikumpulkan } & \text { : 11 Juli } 2019 \\ \text { Direvisi } & : 15 \text { Juli } 2019 \\ \text { Dipublikasi } & : 17 \text { Juli } 2019\end{array}$

\section{ABSTRACT}

The purpose of this paper is to investigating the influence of Artificial Intelligence and Digital Marketing to Consumers Buying Intention. Artificial Intelligence development revolutionize digital marketing as well as customer buying intention and thus boost sales. Artificial Intelligence and Digital Marketing in combination with rapidly developing technologies kind of tracking, buying, cashless. Everything goes to simple touch, will bring opportunities to consumers to having a practical best service. This paper uses quantitative approach that rooted in the Artificial Intelligence, Digital Marketing and Customer Buying Intention Literature, that was carried out using structural equation modeling (SEM) based on partial least square (PLS), with 74 respondents. The contribution of this paper examines consumer perseption, beliefs and behaviours of buying intention of online transportation (gojek) in millenials based on artificial intellegence and digital marketing developing. And a result of this study, artificial intelligence and digital marketing have positively effects to Consumer Buying Intention.In this present research helps service organizations and their management better implications of keep up with the developments of service. This paper talks about artificial intelligence and digital marketing based on consumer buying intention

Tujuan dari makalah ini adalah untuk mengetahu pengaruh Artificial Intellegencedan Digital Marketingterhadap Minat Beli Konsumen Generasi Millenial. Pengembangan Artificial Intelligence merevolusi pada Digital Marketing yang berpengaruh pada minat beli pelanggan,sehingga dapat meningkatkan penjualan. Artificial Intelligence dan Digital Marketingdikombinasikan dengan teknologi yang berkembang pesat seperti tracking, pembelian tanpa uang tunai. Semuanya berjalan dengan sentuhan melalui gadget atau smartphone, hal ini memberikan peluang kepada konsumen untuk memiliki 


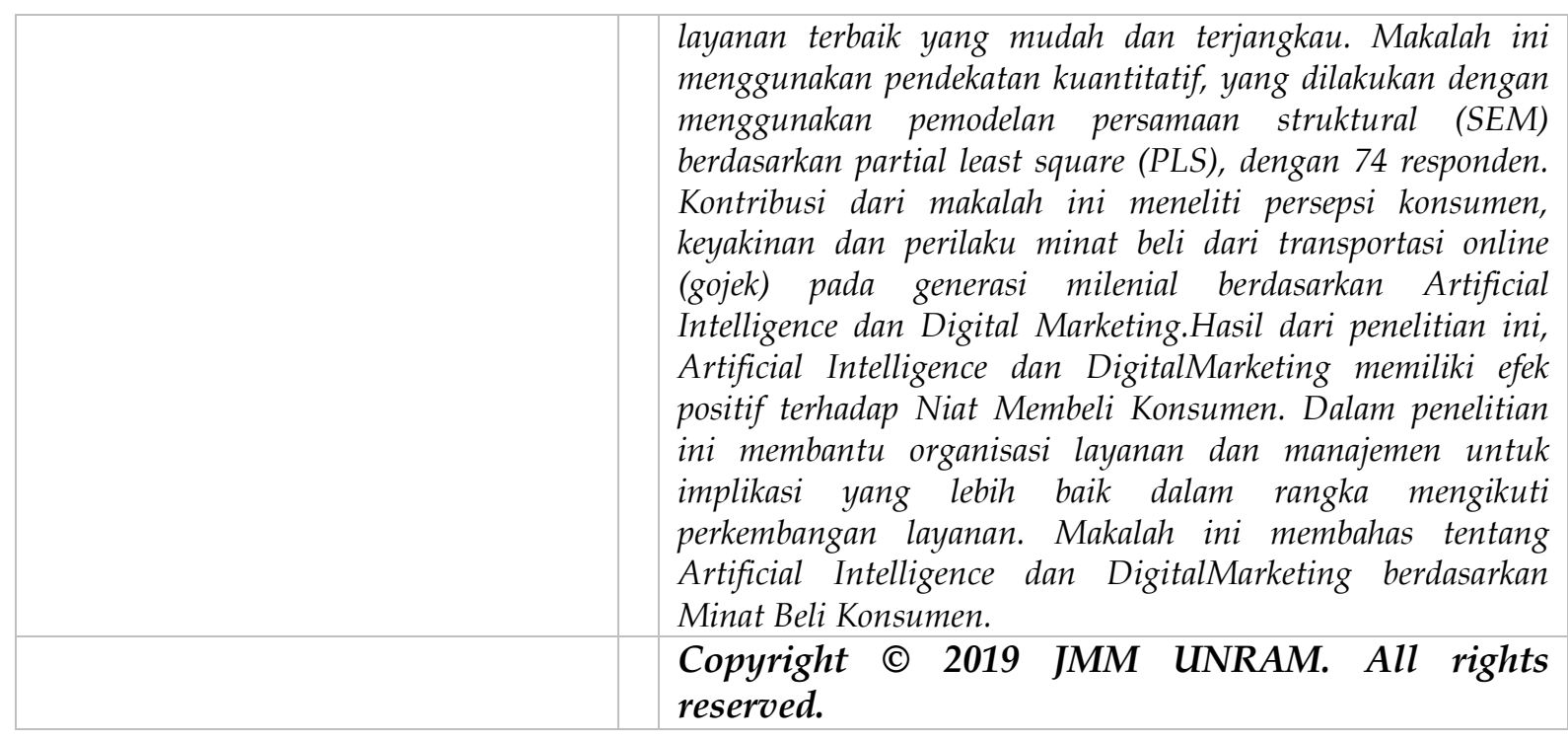

\section{PENDAHULUAN}

Generasi millenial adalah generasi muda yang ditandai dengan penggunaan dan adaptasi teknologi dalam kehidupan sehari-hari mereka, serta nilai-nilai, pengalaman hidup, motivasi, dan perilaku pembelian umum. Generasi ini lahir antara 1980 dan 2000 (Lee \& Kotler, 2016). Generasi millenial sekarang menjadi populasi besar, dan daya beli mereka menjadikan mereka target yang menarik bagi banyak industri konsumen. Oleh karena itu, generasi millenial telah menjadi kelompok yang mengesankan untuk dipelajari karena mereka memiliki perilaku yang berbeda dibandingkan dengan generasi lain, ini adalah alasan mengapa mempelajari mereka merupakan suatu kepentingan dan relevansi (Smith, 2011). Selain itu, yang menjadi ciri generasi millenial adalah bahwa mereka akan mewakili 50 persen konsumsi global pada 2017 (Orozpe, 2014).

Minat beli adalah jenis pengambilan keputusan yang mempelajari alasan untuk membeli merek tertentu oleh konsumen (Shah et al., 2012). Morinez et al. (2007) mendefinisikan minat beli sebagai situasi di mana konsumen cenderung membeli produk tertentu dalam kondisi tertentu. Keputusan pembelian pelanggan adalah proses yang kompleks. Minat beli biasanya terkait dengan perilaku, persepsi dan sikap konsumen. Perilaku pembelian adalah titik kunci bagi konsumen untuk mengakses dan mengevaluasi produk tertentu. Ghosh (1990) menyatakan bahwa niat beli adalah alat yang efektif untuk memprediksi proses pembelian. Niat pembelian dapat diubah di bawah pengaruh harga atau persepsi kualitas dan nilai. Selain itu, konsumen dipengaruhi oleh motivasi internal atau eksternal selama proses pembelian (Gogoi, 2013).Para peneliti telah mengusulkan enam tahap sebelum memutuskan untuk membeli produk, yaitu: kesadaran, pengetahuan, minat, preferensi, persuasi dan pembelian (Kotler \& Armstrong, 2010) (Kawa et al., 2013). Pelanggan selalu berpikir bahwa pembelian dengan biaya rendah, kemasan sederhana dan produk yang kurang dikenal adalah risiko tinggi karena kualitas produk-produk ini tidak dapat dipercaya (Gogoi, 2013).

Ada banyak penelitian sebelumnya yang menguji pengaruh Artificial Intelligence dan Digital Marketing, dan Minat Beli Pelanggan secara individual dan beberapa di antaranya memberikan hasil yang berbeda. Jadi tidak ada kejelasan tentang hubungan antara variabel-variabel ini, dan penelitian perlu dilakukan untuk memperjelas hubungan tersebut. Selain itu, penelitian sebelumnya belum ditemukan untuk menguji efek dari ketiga variabel ini secara bersamaan. Artificial Intelligence dan Digital Marketingmendukung perusahaan dan industri untuk memberikan layanan terbaik, baik kualitas terbaik di milik jmm.unram.ac.id 


\section{NATIONALLY ACCREDITED J OURNAL - DECREE NO. 21/E/KPT/2018}

bersama. Industri harus meningkatkan cara mereka untuk menjangkau generasi millenial, di era ini generasi millenial mengubah cara berpikir konsumen melalui emosi, kebutuhan, keinginan dan permintaan. Peneliti dan organisasi pasar menghabiskan miliaran dolar untuk riset konsumen untuk mengidentifikasi faktor-faktor penting yang mempengaruhi keputusan konsumen. Analisis perilaku konsumen efektif dalam mendeteksi orientasi perilaku konsumen (Thapa, 2011).

Gojek adalah angkutan umum online pertama, yang berbasis internet. Aplikasi transportasi pertama di Indonesia yang didirikan yang dilatarbelakangi oleh lalu lintas padat di kota-kota besar. Gojek melayani banyak layanan, jenis perjalanan, pengiriman makanan, pijat, layanan kebersihan, go-box, yang dapat diakses hanya dari gadget atau ponsel. Awalnya gojek bekerja sama dengan 40 perusahaan. (Internal data Gojek : 2015) Gojek dapat diunduh dari playstore atau appstore, mudah digunakan, dan komunikatif. Gojek diciptakan untuk orang-orang yang membutuhkan gerakan cepat dalam kegiatan, atau misalnya transportasi yang baik. Pelanggan tidak perlu menunggu di jalan atau mencari di pangkalan transportasi. Pemesanan melalui aplikasi gojek segera setelah konsumen memesan secara online, sesuai dengan posisi driver terdekat. Gojek siap melayani pelanggan, berdasarkan lokasi terdekat dari pesanan konsumen. Selanjutnya Nadiem, pendiri gojek, adalah anak muda Indonesia yang berinovasi dan menemukan celah di tengah era yang berkembang di sektor transportasi umum. Gojek memperluas layanan mereka dalam pengiriman makanan, barang-barang, pijat, dll dan dukungan dengan pembayaran tanpa uang tunai yaitu gopay yang merupakan sistem pembayaran yang dibuat dengan ArtificialIntelligence dan dipasarkan dengan cara Digital. Ini telah menjadi hal baru dalam penelitian ini. Oleh karena itu, penelitian ini bertujuan untuk mengetahui pengaruh Artificial Intelligence dan DigitalMarketing terhadap Minat Beli Konsumen Generasi Milenial.

Makalah ini terdiri dari enam bagian yang bagian pertama adalah Latar Belakang, bagian kedua adalah Tinjauan Pustaka dan Pengembangan Hipotesis yang berisi tentang Model Penerimaan Teknologi (TAM), Artificial Intelligence dan Digital Marketing, sertaMinat Beli Pelanggan, dan Hubungan antar variabel, Bagian Ketiga adalah Metodologi, yang jenis penelitian, populasi dan pengambilan sampel dan Instrumen Penelitian serta Pengukurannya. Bagian keempat adalah Analisis Data dan Hasil, bagian ini membahas tentang hasil penelitian ini dengan hasil PLS. Bagian kelima adalah Diskusi dan bagian terakhir adalah Kesimpulan dan Saran yang diharapkan membuat penelitian ini lebih baik di masa depan.

\section{TINJAUAN PUSTAKA DAN PENGEMBANGAN HIPOTESIS}

\subsection{Technology Acceptence Model (TAM)}

TAM pertama dikembangkan oleh Davis (1985) berdasarkan model Theory of Reasoned Action (TRA). Keuntungan paling penting dari TAM adalah parsimony model, yang merupakan model sederhana namun valid. Selain itu, TAM juga telah diuji dengan banyak penelitian yang hasilnya adalah model yang baik terutama jika dibandingkan dengan model TRA (Theory of Reasoned Action)) dan TPB (Theory of Planned Behavior). TAM memiliki lima konstruksi, yaitu Perceived Usefulness, Perceved ease of use, Attitude toward using technology, Behavioral Intention to use, and Actual Technology Use.

\subsection{Artificial Intelligence}

Artificial intelligence (AI)dikerjakan oleh mesin yang menunjukkan aspek kecerdasan manusia, semakin banyak digunakan dalam pelayanan dan saat ini merupakan sumber utama inovasi (Rust dan Huang 2014). Perkembangan ini telah membuat beberapa orang 


\section{NATIONALLY ACCREDITED J OURNAL - DECREE NO, 21/E/KPT/2018}

menyatakan bahwa saat ini manusia berada dalam revolusi industri keempat di mana teknologi mengaburkan batas antara bidang fisik, digital, dan biologis (Schwab 2017). Ada dua aliran penelitian utama yang terkait dengan kemajuan AI. Literatur layanan dan teknologi cenderung berfokus pada sisi positif penggunaan teknologi AI, sedangkan literatur ekonomi cenderung berfokus pada efek AI pada pekerjaan. Literatur layanan cenderung berfokus pada aplikasi teknologi cerdas (Colby, Mithas, dan Parasuraman 2016; Marinova dkk. 2017; Rafaeli dkk. 2017) Pemasaran Artificial Intelligence adalah metode pemanfaatan data pelanggan untuk mengantisipasi pelanggan berikutnya bergerak dan meningkatkan perjalanan pelanggan. ArtificialIntelligencemenawarkan cara untuk menjembatani kesenjangan antara sains data dan eksekusi dengan menyaring dan menganalisis data rusak yang sangat besar yang dulunya merupakan proses yang tidak dapat diatasi.

\subsection{Minat Beli Konsumen}

Menurut Kotler dan Keller (2003: 181), Minat Beli Konsumenadalah semua pengalaman mereka dalam belajar, memilih, menggunakan, peristiwa memilih suatu produk. Yang kurang lebih berarti minat beli konsumen adalah perilaku konsumen di mana konsumen memiliki keinginan untuk membeli atau memilih suatu produk, berdasarkan pengalaman dalam memilih, menggunakan dan mengkonsumsi atau bahkan menginginkan suatu produk. Schiffman dan Kanuk (2004: 25), menjelaskan bahwa pengaruh eksternal, kesadaran akan kebutuhan, pengenalan produk dan evaluasi alternatif adalah hal-hal yang dapat mengarah pada minat beli konsumen. Pengaruh eksternal ini terdiri dari upaya pemasaran dan faktor sosial budaya. Super and Crites (Lidyawatie, 1998) menjelaskan bahwa ada beberapa faktor yang mempengaruhi minat, yaitu:

a) Perbedaan pekerjaan, yang berarti bahwa dengan perbedaan dalam pekerjaan seseorang dapat memperkirakan minat pada tingkat konsumsi yang ingin dicapai, kegiatan yang dilakukan, penggunaan waktu luang, dan lain-lain.

b) Perbedaan sosial ekonomi, artinya seseorang yang memiliki sosial ekonomi tinggi akan lebih mudah mencapai apa yang diinginkannya daripada orang yang memiliki sosial ekonomi rendah.

c) Perbedaan hobi atau hobi, artinya bagaimana seseorang menggunakan waktu luangnya.

d) Perbedaan gender, artinya kepentingan perempuan akan berbeda dari minat laki-laki, misalnya dalam pola belanja.

e) Perbedaan usia, artinya usia anak-anak, remaja, dewasa dan orang tua akan berbeda minat pada suatu barang, aktivitas objek dan seseorang.

\subsection{Hubungan antaraArtificial Intelligenceand Minat Beli Konsumen}

Dilengkapi dengan penelitian terbaru yang mendukung pengaruh Artificial Intellegence terhadap Minat Beli Konsumen, ditemukan bahwa Artificial Intelligenceberhasil digunakan dalam kesehatan dan melacak secara otomatis menentukan dosis obat yang optimal untuk tanggapan jangka panjang, ini memperkuat loyalitas pelanggan pada perusahaan (Londhe dan Bashin: 2019). Penelitian lebih lanjut oleh Shin, Tada dan Managi (2019) meneliti teknologi mengemudi otomatis yang termasuk dalam transportasi dunia, secara signifikan mengurangi jumlah kecelakaan yang disebabkan oleh kesalahan manusia dan kemacetan jalan. Survei sejak 2015 melaporkan bahwa Niat Beli Positif dan meningkat. Chen-chen dan Tsai (2017) mengembangkan aplikasi mobile tourism berbasis lokasi yang dipersonalisasi untuk perencanaan perjalanan, sehingga perjalanan dapat lebih efektif dan efisien. Dengan Artificial Intelligence, itu membuktikan bahwa persepsi tentang kegunaan dan kemudahan penggunaan mempengaruhi minat seseorang untuk melakukan atau 


\section{NATIONALLY ACCREDITED J OURNAL - DECREE NO, 21/E/KPT/2018}

membeli sesuatu. Artificial Intelligencetidak hanya dapat memberikan responsif, tetapi juga mengurangi kebutuhan staf yang dapat mengurangi biaya karyawan. (Bachdar: 2018).

H1: Artificial Intelligenceberpengaruh positif dan signifikan terhadap Minat Beli Konsumen

\subsection{Hubungan antaraArtificial Intelligencedan DigitalMarketing}

Ada beberapa fakta dan penelitian yang telah dilakukan terkait dengan pengaruh kecerdasan buatan pada pemasaran digital. Dengan kemampuan Artificial Intelligenceuntuk mengolah data menjadi wawasan yang bermanfaat; dapat membantu penjual yang sekarang merajalela menggunakan media sosial sebagai alat pemasaran. Dengan 2,4 miliar orang di dunia berinteraksi dan berbagi konten melalui media sosial, serta kecanggihan Artificial Intelligenceyang berkembang pesat, Artificial Intelligencedan media sosial akan memiliki masa depan yang cerah di ranah pemasaran (Permana: 2017). mencatat semakin besar sejarah pelanggan berinteraksi,bagaimana dan dengan siapa pelanggan berinteraksi. Sehingga kebutuhan, preferensi dan perilaku pelanggan telah tersistematis. Dan memungkinkan untuk menargetkan dan retarget dalam membuat sistem produksi dan dapat meningkatkan dan mengontekstualisasikan nilai data. (Sterne: 2017). Menurut penelitian dari Radicati (2018) ada 34\% orang di seluruh dunia atau sekitar 2,5 miliar menggunakan pemasaran email dan meningkat setiap tahun.

H2 : Artificial Intelligenceberpengaruh positif signifikan terhadap Digital Marketing

\subsection{Hubungan antara Digital Marketingdan Minat Beli Konsumen}

Penelitian yang telah dilakukan terkait dengan Pengaruh Pemasaran Digital terhadap Minat Beli. Katherine Research Taken Smith (2011) menemukan bahwa Dengan meningkatnya penggunaan media digital oleh konsumen, semakin banyak perusahaan menggunakan pemasaran digital untuk mencapai target pasar perusahaan. Apalagi generasi milenial, pemasaran digital memberi dampak positif pada penjualan. Pemasaran media sosial merangsang faktor-faktor eksternal dan memengaruhi persepsi batin konsumen, dan pada akhirnya memengaruhi minat beli konsumen. Akhirnya sesuai dengan karakteristik niat pembelian konsumen berdasarkan pemasaran media sosial, ada pengambilan keputusan dan dukungan untuk mengembangkan perdagangan elektronik untuk memberikan referensi bagi perusahaan (Maoyan, Zhujunxuan, Sangyang: 2014) Media sosial yang teridentifikasi menciptakan lebih banyak keuntungan. Peran media sosial dalam pengembangan e-commerce menjadi perdagangan sosial menunjukkan bahwa media sosial memfasilitasi interaksi sosial konsumen yang mengarah pada peningkatan kepercayaan dan niat untuk membeli. (Hajli: 2013)

H3: Digital Marketingberpengaruh positif dan signifikan terhadap Minat Beli Konsumen

\subsection{Research Framework}

Based on literature review and hypotheses as explained aboved, we proposed and examined the research framework that presented in figure 1

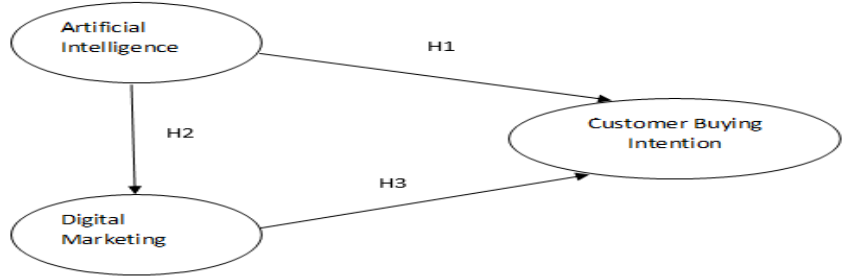

Figure 1.

Kerangka Konseptual 


\section{METODOLOGI}

\subsection{Jenis Penelitian}

Jenis penelitian yang digunakan dalam penelitian ini adalah penelitian asosiatif. dengan pendekatan kuantitatif. Menurut Suliyanto (2006), penelitian asosiatif adalah penelitian yang bertujuan untuk mengetahui hubungan atau pengaruh antara dua variabel atau lebih. Populasi dalam penelitian ini adalah wanita generasi Y (milenium) di Kota Mataram. Jumlah sampel yang digunakan adalah 100 responden, dengan kriteria sebagai berikut : Aged from 19 to 34 years

a. Berusia 19-34 tahun

b. Menggunakan media sosial secara aktif

\subsection{Populasi dan Sample}

Penelitian ini dilakukan dengan memberikan kuesioner secara online kepada 74 responden yang dijadikan sampel. Dalam penelitian ini, millenials secara global, kriterianya akan terlihat dalam deskripsi kisaran karakteristik responden. Deskripsi karakteristik responden dibagi menjadi beberapa kategori, termasuk usia responden, pekerjaan responden, dan pendapatan bulanan responden.

Berdasarkan hasil analisis, dapat diketahui bahwa responden yang mendominasi adalah rentang usia antara 26 tahun dan 28 tahun. Usia ini dapat dianggap sebagai usia dewasa, baik wanita atau pria. Selanjutnya, untuk kategori pekerjaan, responden yang mendominasi adalah mahasiswa. Dalam hal ini, siswa yang dituju adalah mereka yang sedang menempuh studi tingkat Diploma, Sarjana, atau Pascasarjana, sehingga ada variasi usia dalam kategori ini.

\subsection{Prosedur Analisis Data}

Skala pengukuran variabel yang digunakan dalam penelitian ini adalah Skala Likert. Jawaban alternatif menggunakan skala Likert memiliki gradasi dari sangat tidak setuju ke sangat setuju yang dibuat menjadi 5 (lima) pilihan jawaban. Sementara itu, teknik analisis data menggunakan teknik Stuctural Equation Modeling (SEM) berdasarkan Partial Least Squares (PLS) menggunakan perangkat lunak SmartPLS versi 3.0. PLS adalah analisis SEM berbasis varian yang secara bersamaan dapat menguji model pengukuran dan juga dapat menguji model struktural (Abdillah \& Jogiyanto, 2009). Model pengukuran (Inner Model) digunakan untuk uji validitas dan uji reliabilitas, sedangkan model struktural (Outer Model) digunakan untuk uji kausalitas (uji hipotesis dengan model prediksi).

\subsection{Instrumen dan Pengukuran Penelitian}

Pengukuran penelitian ini menggunakan Likert (2005) yang skala mulai dari $1=$ sangat tidak setuju sampai 5 = sangat setuju. Mengenai pengujian validitas, penelitian ini menggunakan validitas konstruk dengan pengujian analisis faktor konfirmatori yang diambil dengan teknik korelasi oleh Pearson Product Moment yang menganalisis-CorrelateBivariate-Person, menggunakan two tailed dengan signifikansi $5 \%$, sedangkan $\mathrm{N}=10$, jadi $\mathrm{r}$ tabel $=0,497$. Tabel 3.4 menyajikan hasil pengujian validitas instrumen penelitian yang digunakan dalam penelitian ini.

Table 3.4

Results of research instruments

\begin{tabular}{|c|c|c|}
\hline Item & R Hitung & Keterangan \\
\hline $\mathrm{X} 1.1$ & 0.688 & valid \\
\hline $\mathrm{X} 1.2$ & 0.663 & valid \\
\hline $\mathrm{X} 1.3$ & 0.666 & Valid \\
\hline
\end{tabular}

jmm.unram.ac.id 
NATIONALLY ACCREDITED J OURNAL - DECREE NO. 21/E/KPT/2018

\begin{tabular}{|c|c|c|}
\hline $\mathrm{X} 1.4$ & 0.663 & valid \\
\hline $\mathrm{X} 1.5$ & 0.663 & valid \\
\hline $\mathrm{X} 2.1$ & 0.771 & valid \\
\hline $\mathrm{X} 2.2$ & 0.910 & valid \\
\hline $\mathrm{X} 2.3$ & 0.935 & valid \\
\hline $\mathrm{X} 2.4$ & 0.779 & valid \\
\hline $\mathrm{Y} .1$ & 0.935 & valid \\
\hline $\mathrm{Y} .2$ & 0.758 & valid \\
\hline Y.3 & 0.900 & valid \\
\hline Y.4 & 0.803 & valid \\
\hline Y.5 & 0.822 & valid \\
\hline
\end{tabular}

Source : Primary Data, Processed on April 2019

\section{ANALISIS DATA DAN HASIL}

\subsection{Convergent Validity}

Convergent Validity untuk indikator reflektif dapat dilihat dari nilai faktor pemuatan yang disarankan yang lebih besar dari 0,70. Ini berarti bahwa korelasi antara indikator dan variabel dengan nilai loading factor lebih dari 0,70 dapat dimasukkan dalam analisis selanjutnya. Dengan penelitian pengembangan rentang pemuatan skala 0,50 - 0,60 masih dapat diterima (Imam Ghozali: 2006) Berikut ini adalah Model Luar setelah estimasi. Tabel 4.1 menyajikan tabel Convergent Validity dari Artificial Intelligence, DigitalMarketing dan Minat Beli Konsumen.

Table 4.1

Convergent Validity

\begin{tabular}{|c|c|c|c|}
\hline Constructs & \multicolumn{2}{|l|}{ Items } & Outer Loadings \\
\hline \multirow{5}{*}{$\begin{array}{c}\text { Artificial Intelligence } \\
\text { (X1) }\end{array}$} & Expert System & $X 1.1$ & 0.965 \\
\hline & Natural Language System & X1.2 & 0.898 \\
\hline & Robotics and Sensoric & X1.3 & 0.914 \\
\hline & Computer Vision & $X 1.4$ & 0.924 \\
\hline & Intelligent Computer & X1.5 & 0.968 \\
\hline \multirow{4}{*}{ Digital Marketing $(x 2)$} & Website & X3.1 & 0.951 \\
\hline & Sosial Media & $X 3.2$ & 0.934 \\
\hline & Email & X3.3 & 0.912 \\
\hline & Adwords & X3.4 & 0.931 \\
\hline \multirow{5}{*}{$\begin{array}{c}\text { Minat Beli Konsumen } \\
(Y)\end{array}$} & Attention & $Y .1$ & 0.965 \\
\hline & Perhatian Konsumen & $Y .2$ & 0.911 \\
\hline & Rasa Ingin Memiliki & $Y .3$ & 0.912 \\
\hline & Tahap Akhir & $Y .4$ & 0.907 \\
\hline & Keputusan & $Y .5$ & 0.971 \\
\hline
\end{tabular}

Source : Primary Data, Processed on April 2019

Berdasarkan hasil analisis, dapat dilihat bahwa semua indikator memiliki nilai loading factor lebih dari 0,70, sehingga artinya, diterima.

Berikut ini adalah hasil dari Outer Loadingyang ditunjukkan pada Gambar 4.1

\section{Figure 4.1}

The Result of Outer Loadings after Re-Estimation 


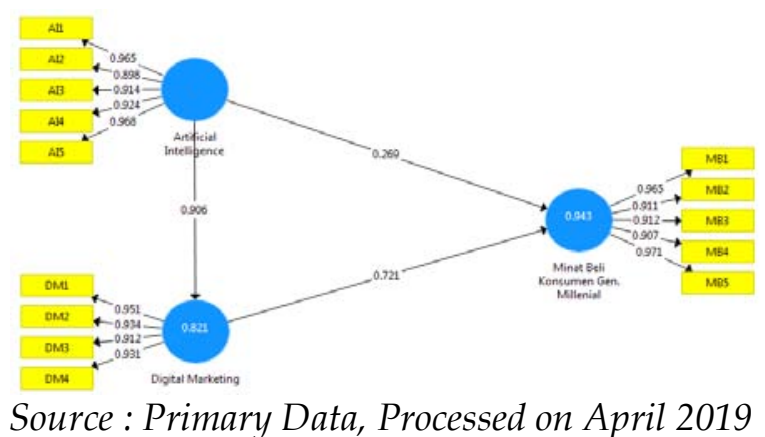

Berdasarkan gambar di atas, dapat dilihat bahwa indikator variabel memenuhi kriteria dengan nilai pembebanan luar diatas 0,70 .

\subsection{Discriminant Validity}

Discriminat validity dari model pengukuran dengan indikator refleksif dinilai berdasarkan cross loading pengukuran dengan konstruk. Jika korelasi konstruk dengan item pengukuran lebih besar daripada ukuran konstruk lainnya, maka hal itu menunjukkan bahwa konstruk laten memprediksi ukuran pada blok mereka lebih baik daripada ukuran pada blok lainnya. Cara lain mengukur discriminat validity adalah melihat nilai square root of average variance extracted (AVE). Nilai yang disarankan adalah di atas 0,5. Berikut adalah nilai AVE dalam penelitian yang dihasilkan pada Tabel 4.2

\section{Tabel 4.2}

The Square Roots Value of AVE

\begin{tabular}{|c|c|}
\hline Constructs & AVE \\
\hline$X 1$ & $\mathbf{0 . 8 7 3}$ \\
\hline$X 2$ & $\mathbf{0 . 8 6 9}$ \\
\hline$Y$ & $\mathbf{0 . 8 7 1}$ \\
\hline
\end{tabular}

Source : Primary Data, Processed on April 2019

\subsection{Composite Reliability}

Pengujian selanjutnya adalah composite reliability dari blok indikator yang mengukur konstruk. Suatu konstruk dikatakan reliable jika nilai composite reliability di atas 0,60 (Imam Ghozali, 2006). Berikut ini hasil outer model loading yang menunjukkan composite reliabilty masing-masing konstruk pada tabel 4.3

Table 4.3

Composite Reliability

\begin{tabular}{|c|c|}
\hline Constructs & $\begin{array}{l}\text { Composite } \\
\text { Reliability }\end{array}$ \\
\hline$X 1$ & $\mathbf{0 . 9 7 2}$ \\
\hline$X 2$ & $\mathbf{0 . 9 6 4}$ \\
\hline$Y$ & $\mathbf{0 . 9 7 1}$ \\
\hline
\end{tabular}

Source : Primary Data, Processed on April 2019

\subsection{Inner Model}

Menilai inner model adalah mengevaluasi hubungan antar konstruk laten seperti yang telah dihipotesiskan dalam penelitian ini. Berikut adalah nilai R-Square pada konstruk pada tabel 4.4

\section{Table 4.4}

R-Square and R-Square Adjusted

jmm.unram.ac.id 
NATIONALLY ACCREDITED J OURNAL - DECREE NO. 21/E/KPT/2018

\begin{tabular}{|c|c|}
\hline Constructs & R-Square \\
\hline$Y$ & 0.821 \\
\hline$Z$ & 0.5943 \\
\hline
\end{tabular}

Source : Primary Data, Processed on April 2019

Tabel di atas memberikan nilai 0.821 untuk konstruk Digital Marketing, yang berarti bahwa Artificial Intelligence mampu menjelaskan varians Digital Marketing sebesar $82.1 \%$, sedangkan $7.9 \%$ dipengaruhi oleh faktor-faktor lain. Selain itu nilai 0.943 untuk konstruk Minat Beli yang berarti bahwa Artificial Intelligence dan Digital Marketing mampu menjelaskan varians Minat Beli Konsumen sebesar 94.3\% sedangkan sisanya sebesar 7.7\% dipengaruhi oleh faktor-faktor lain.

\subsection{Final Results}

Signifikansi parameter yang diestimasi memberikan informasi yang sangat berguna mengenai hubungan antar variable penelitian. Dasar yang digunakan dalam menguji hipotesis adalah nilai yang terdapat pada output path coefficient yaitu Original Sample, STDEV, T-Values, P-Values.

Dalam PLS, pengujian secara statistic setiap hubungan yang dihipotesiskan dilakukan dengan menggunakan simulasi. Dalam hal ini dilakukan dengan metode bootsrap terhadap sampel yaitu dengan perhitungan bootstrapping untuk uji hipotesis. Pengujian dengan bootstrap ini djuga dimaksudkan duntuk meminimalkan masalah ketidaknormalan penelitian. Berikut ini adalah hasil perhitungan bootstrapping untuk pengujian hipotesis pada tabel 5.1

Table 5.1

Hasil dari Test Hipotesis

\begin{tabular}{|l|c|c|c|c|c|}
\hline \multicolumn{1}{|c|}{ Hipotesis } & $\begin{array}{c}\text { Coefficien } \\
\mathbf{t}\end{array}$ & STDEV & T Statistics & P Value & Kesimpulan \\
\hline $\begin{array}{l}\text { Artificial Intelligence-> } \\
\text { Digital Marketing }\end{array}$ & 0.906 & 0.039 & 23.053 & 0.000 & $\begin{array}{c}\text { Positive and } \\
\text { Significant }\end{array}$ \\
\hline $\begin{array}{l}\text { Artificial Intelligence-> } \\
\text { Customer Buying Intention }\end{array}$ & 0.269 & 0.108 & 2.478 & 0,014 & $\begin{array}{c}\text { Positive and } \\
\text { Significant }\end{array}$ \\
\hline $\begin{array}{l}\text { Digital Marketing-> } \\
\text { Customer Buying Intention }\end{array}$ & 0.721 & 0.108 & 6.706 & 0.000 & $\begin{array}{c}\text { Positive and } \\
\text { Significant }\end{array}$ \\
\hline
\end{tabular}

Berikut ini adalah pengujian hipotesis dalam penelitian ini.

Hipotesis 1 menyatakan bahwa Artificial Intelligencememiliki efek positif pada Digital Marketing, menunjukkan koefisien jalur 0,906 dengan t-statistik 23,053 yang berarti bahwa nilainya lebih besar dari nilai t-tabel $(1,992)$ dengan tingkat signifikansi $5 \%$. Hasil ini berarti bahwa Artificial Intelligencememiliki hubungan positif dan signifikan dengan Digital Marketing. Hipotesis 2 menyatakan bahwa Artificial Intelligencememiliki efek positif pada Minat Beli Generasi Millenial, menunjukkan nilai koefisien jalur sebesar 0,269 dengan nilai t-statistik 2,478 yang berarti bahwa nilainya lebih besar dari t-tabel $(1,992)$ dengan tingkat signifikansi 5\%. Hasil ini berarti bahwa Artificial Intelligencememiliki hubungan positif dan signifikan dengan Minat Beli Generasi Millenial. Hipotesis 3 menyatakan bahwa Digital Marketing memiliki pengaruh positif terhadap Minat Beli Generasi Millenial menunjukkan nilai koefisien jalur sebesar 0,721 dengan nilai t-statistik 6,706 yang berarti bahwa nilainya lebih besar dari t-tabel $(1,992)$ dengan tingkat signifikansi 5\%. Hasil ini berarti bahwa DigitalMarketingmemiliki hubungan positif dan signifikan dengan Minat Beli Generasi Milenial. 


\section{PEMBAHASAN}

Berdasarkan hasil analisis, dapat diketahui bahwa variabel Artificial Intelligence (X1) yang dinilai berdasarkan indikator termasuk sistem Pakar, Sistem Bahasa Alam, Computer Vision, dan Intellegent Computermemiliki efek positif dan signifikan terhadap Minat Beli Konsumen. (Y). Hal ini dapat dilihat dari nilai t-statistik yang lebih besar dari batas nilai pada t-tabel $(1,960)$ dengan tingkat signifikan $5 \%$ yang setara dengan 2,478. Dengan demikian, Hipotesis 1 dalam penelitian ini diterima. Selain itu, McKinsey Global Institute menyatakan bahwa teknologi Intelegensi Buatan akan menyumbang 1,2\% dari Gross Domestic Product (GDP) tahunan, bahkan untuk 10 tahun ke depan. Teknologi Buatan dapat menghasilkan \$ 13 trilyun untuk Pasar Ekonomi Global pada tahun 2030 (McKinsey: 2019)

Berdasarkan hasil analisis, dapat diketahui bahwa variabel Artificial Intelligence (X1) yang dinilai berdasarkan indikator sistem Pakar, Sistem Bahasa Alam, Computer Vision, dan Intelligent Computer memiliki pengaruh positif dan signifikan terhadap Pemasaran Digital ( X2) Hal ini dapat dilihat dari nilai t-statistik yang lebih besar dari batas nilai dalam t-tabel $(1,960)$ dengan tingkat signifikan of 5\% yang setara dengan 23,053. Dengan demikian, hipotesis 2 dalam penelitian ini diterima Penelitian ini didukung oleh penelitian Sterne (2017), menemukan bahwa semakin besar data, semakin besar pula sejarah interaksi pelanggan. Dalam penelitian lain ditemukan bahwa kemampuan ArtificialIntelligence sesuai dengan minat beli konsumen, sehingga membuat suatu industri membuat produk yang sesuai dengan kebutuhan pelanggan (Chard: 2018).

Berdasarkan hasil analisis, dapat dilihat bahwa variabel Digital Marketing (X2) yang dinilai berdasarkan indikator Website, Media Sosial, Email, dan Adwords memiliki pengaruh positif dan signifikan terhadap Minat Beli Konsumen $(Z)$. Ini dapat dilihat dari nilai tstatistik yang lebih besar dari batas nilai dalam t-tabel $(1,960)$ dengan tingkat signifikan of $5 \%$ yang setara dengan 6,706. Dengan demikian, Hipotesis 3 dalam penelitian ini diterima. Penelitian Katherine Taken Smith pada 2011 menemukan hasil yang sama bahwa semakin meningkatnya Media Digital oleh konsumen, semakin baik perusahaan mencapai target pasar.

\section{KESIMPULAN}

Hasil dari analisis data menjawab ketiga hipotesis yang diajukan dan menjawab pertanyaan kuisoner penelitian. Artificial Intelligencetermasuk didalamnya sistem Pakar, Sistem Bahasa Alami, Computer Vision, dan Intelligent Computer memiliki Efek Positif dan Signifikan terhadap Minat Beli Konsumen (H1). dan Pemasaran Digital (H2). Dan bahwa Digital Marketingyang dicirikan oleh Website, Media Sosial, Email, dan Adwords memiliki efek positif dan signifikan terhadap Niat Membeli Konsumen (H3). Di antara semua responden yang diusulkan, Robotika dan Sensorik dalam Artificial Intelligence telah ditemukan sebagai yang paling signifikan untuk memengaruhi Minat BeliKonsumen. Walaupun Email pada Digital Marketingditemukan sebagai indikator terendah, namun tetap signifikan, sehingga diharapkan Transportasi Online (gojek) perlu mencari tahu bagaimana mengembangkan misalnya melalui verifikasi email untuk anggota baru.

Patterson (2018) menyatakan bahwa Robotic in Service berdasarkan Artificial Intelligence dapat ditindaklanjuti dan diperluas di lebih banyak sektor terutama dalam melayani pelanggan. Selain itu, data terbaru dari McKinsey Global Institute menyatakan bahwa teknologi Artificial Intelligence (AI) diperkirakan berkontribusi 1,2\% dari produk gross domestic product (GDP)bahkan untuk 10 tahun ke depan. McKinsey menjelaskan dalam CNBC, Kamis (6/9/2018), teknologi Artificial Intelligence dapat memberikan USD 13 
triliun untuk pasar ekonomi global pada tahun 2030. "Tanpa Artificial Intelligence, Cina mungkin menghadapi tantangan untuk mencapai tingkat pertumbuhan targetnya. Implikasi untuk pengetahuan bukan hanya untuk hasil penelitian, tetapi untuk media yang bisa berkembang menjadi teori dan metode yang lebih baik.Penelitian ini bisa menjadi referensi untuk berinovasi dan memperluas topik ini. Diharapkan penelitian ini dapat dikembangkan lebih dalam agar dapat memberikan dasar pengetahuan untuk penelitian serupa, dan semoga saja untuk pemecah masalah.

\section{DAFTAR PUSTAKA}

Abdillah, Willy., dan Hartono, Jogiyanto. (2015). Partial Least Square (PLS) Alternatif Structural Equational Modeling (SEM) dalam Penelitian Bisnis. Edisi 1. Yogyakarta : Penerbit Andi.

A Munshi, MSS MUNSHI (2012), "Digital matketing: A new buzz word", International Journal of Business Economics \& Management Research, Vol.2 Issue 7.

Bachdar, Saviq. (2018). Sejauh Mana Penerapan Artificial Intelligence Dalam ECommerce Indonesia?

Chaffey, D. (2011). E-Business and E-Commerce Management : Strategy, Implementation, and Practice (5 th ). Pearson Education

Davis C. 1985 The Marketing/ Small Enterprise Paradox: A Research Agenda

Ghosh, A. 1990. Retail management. Chicago: Drydden press

Ghozali, I. (2006) The Influence of Culture on B2B in Thailand. Journal of Global Information Technology Management (Ivy League Publishing). 10-38

Gogoi, B. 2013. Study of antecedents of purchase intention and its effect on brand loyalty of private label brand of apparel. International Journal of Sales \& Marketing. 73-86 Hajli M. N., (2014) A Study Of The Impact Of Social Media On Consumers

Herman L.E (2018) Techno-Entrepreuneurial Relationship Marketing to ignite the SMEs Marketing Performance in Indonesia

J Chandler Pepelnjak,"Measuring ROI beyond the last ad", Atlas Institute, Digital Marketing Insight, 2008.

Kotler, P., \& Keller, K. L. (2015). Marketing Management.15th Edition. London: Pearson Education

Kotler, P., \& Armstrong, G. 2012. Principle of Marketing, 14th ed. Pearson

Lautiainen, T. (2015) Factors affecting consumers buying decision in the selection of a coffee brand

Lidyawatie. (2008). Manajemen Pemasaran dan Pemasaran Jasa. Bandung: Alfabeta.

Mort, Sullivan, Drennan, Judy, (2002) Europan Journal of Marketing

Orozpe (2014) The Adoption of the Green Marketing in the Millennium Generation. International Journal of Marketing Studies, 1918-7203

Patterson, Paul., Wirtz, Jochen dkk. (2018), "Brave New world : service robots in the frontline"

Permana A., "Pelajari Artificial Intelligence, Media Sosial, dan Masa Depan Pemasaran Digital" https://www.trentech.id/pelajari-artificial-intelligence-mediasosial-dan-masa-depan-pemasaran-digital/ (diakses 23 Desember 2018)

Radicati S. Radicati Group Email Statistcis Report 2014-2018 available at http://www.radicati.com Schiffman and Kanuk. 1997. Consumer Behaviour,6th edition, Prentice Hall, New Jersey

Rai, N. (2013), "Impact of Advertising On Consumer Behaviour And Attitude with Reference to Consumer Durables"

Sathya, P. (2015), "A Study on Digital Marketing and Its Impact"

jmm.unram.ac.id 
NATIONALLY ACCREDITED J OURNAL - DECREE NO. 21/E/KPT/2018

Shah, H., Aziz, A., Jaffari, A. R., Waris, S., Ejaz, W., Fatima, M. and Sherazi., K. 2012. The Impact of Brands on Consumer Purchase Intentions. Asian Journal of Business Management. 105-110.

Smith, K. (2011). Digital Marketing Strategies that Millennials Find Appealing, Motivating, or just annoying

Sterne, Jim (2017), Artificial Intelligence for Marketing, Rising Media Inc. John Wiley and Sons Inc.

Thapa, A.(2011). Consumer switching behaviour: a study of shampoo brands, national monthly refereed journal of reasearch in commerce \& management, volume no.1, issue no.9 Purchase Intention Case Study: the Agencies of Bono Brand Tile in Tehran

Yang, S., X. Chen and X. Shen, 2017. An exploratory study of customer satisfaction with international student recruitment agencies: A case study in New Zealand. International Journal of Business and Management, 12(11): 130.

Zhunjunxuan, Maoyan, Sangyang, (2014) “Consumer Purchase Intention Research Based on Social Media Marketing"' 